\title{
Estrogen Secretion Inhibition
}

National Cancer Institute

\section{Source}

National Cancer Institute. Estrogen Secretion Inhibition. NCI Thesaurus. Code C41506.

Estrogen Secretion Inhibition consists of interference with, or restraint of, activities involved in release into the bloodstream by the ovaries of a class of steroid substances (estrogens) that have a specific regulatory effect on the activity of cells involved in development and maintenance of secondary female sex characteristics and control of the cyclical changes in the reproductive cycle, as well as pregnancy maintenance and an anabolic effect on protein metabolism and water retention. Alteration of positive or neg ative feedback mechanisms can affect hormone release. 